\title{
CINEMA E EDUCAÇÃO: O QUE PODE O CINEMA?
}

\author{
Alexander de Freitas * \\ Karyne Dias Coutinho ${ }^{* *}$
}

\begin{abstract}
RESUMO
Problematizando o uso repetido e dominante do cinema em educação, enquanto recurso didático-metodológico para o ensino-aprendizagem e como disciplinador de condutas e modos de ser, este artigo pretende pensar "o que pode o cinema para a educação?". A partir das ideias de Gilles Deleuze foi possível investigar e experimentar, em projetos de extensão e pesquisa desenvolvidos junto ao Centro de Educação da UFRN, três usos diferenciais do cinema em educação: 1) o cinema como produtor de choques e violências ao pensamento, que forçam a pensar; 2) o cinema como resistência às representações dominantes, aos estereótipos e aos clichês; 3) o cinema como potencializador da cartografia da contemporaneidade e dos modos de subjetivação contemporâneos. Consolidando estas outras potencialidades do cinema para pensar a educação, o artigo apresenta, como resultado das pesquisas realizadas, uma breve cartografia dos sujeitos contemporâneos, produzida com o filme Ken Park (Larry Clarck, EUA, 2002).
\end{abstract}

Palavras-chave: Cinema. Educação. Gilles Deleuze. Cartografia. Contemporaneidade.

\begin{abstract}
Problematizing the repeated and prevailing use of cinema in education, as a didactic-methodological resource for teaching-learning process and
\end{abstract}

\footnotetext{
* Doutor em Educação pela Universidade de São Paulo. Professor adjunto de Didática para os Cursos de Licenciatura do Centro de Educação da Universidade Federal do Rio Grande do Norte. E-mail: xander@usp.br

** Doutora em Educação pela Universidade Federal do Rio Grande do Sul. Professora adjunta de Currículos e Programas do Curso de Pedagogia do Centro de Educação da Universidade Federal do Rio Grande do Norte. E-mail: kcout@terra.com.br
} 
as disciplinarian of behaviors and ways of being, this article aims to think "what can the cinema do for education?". From the ideas of Gilles Deleuze it was possible to investigate and to experiment, in research and extension projects developed in the Education Center of UFRN, three differential use of cinema in education: 1) the cinema as a producer of shocks and violence to the thought, that force to think; 2) the cinema as resistance to prevailing representations, stereotypes and clichés; 3) the cinema as an enhancer of cartography of the contemporaneity and of the contemporary modes of subjectification. Consolidating these other potentiality of the cinema for thinking the education, the article presents, as a result of research conducted, a brief cartography of contemporary subjects, produced with the film Ken Park (Larry Clark, USA, 2002)

Keywords: Cinema. Education. Gilles Deleuze. Cartography. Contemporaneity.

"Imitadores, corja servil" (Horácio)

\section{O que pode o cinema?}

Basta justapor estas duas palavras, "cinema" e "educação", para ver emergir daí toda uma matriz que comanda o que se faz com o cinema em educação: um uso viciado, dominante, clichê; uma prisão. É suficiente uma pesquisa através destes nossos rápidos e modernos recursos midiáticos indexados por palavras para podermos evidenciar que a associação que se faz entre "cinema" e "educação" pertence a uma matriz discursiva utilitarista, repetida e hegemônica.

Trata-se geralmente de uma função didática do cinema em educação, isto é, seu uso didático-metodológico como metáfora epistemológica, para transposição didática de ideias, situações ou conceitos, como imagem do pensamento, enfim, como recurso facilitador da relação ensinoaprendizagem. Assim, o uso do cinema em educação se dá de modo geral para ensinar, memorizar, repetir, explicitar, explicar, tornar claro, enfatizar, desde conceitos, saberes, períodos históricos e movimentos artísticos, culturais e sociais, indo até um uso predominantemente disciplinador e normalizador ${ }^{1}$.

1 Estas últimas funções, reguladora e regulamentadora de condutas, ficam bastante evidentes, por exemplo, no uso freqüente que se faz do cinema na educação ambiental ou nas campanhas de prevenção às drogas e às doenças sexualmente transmissíveis. 
Curioso é que padecemos de um esquecimento que recusa ser lembrado: que o cinema foi um dos mais importantes e um dos mais utilizados recursos didáticos para pregar a moral nazista, como bem mostra o premiado documentário Arquitetura da destruição, de Peter Cohen (ALEMANHA, 2004). Nesse sentido, frise-se aqui, em relação ao campo da educação, a escassez de críticas à ilusão cinematográfica reiteradamente esquecida como potente maquinaria de produção e difusão de modos de ser e de morais. Ao contrário disso, o uso do cinema em educação é, na maioria das vezes, tido como positivo, inovador, diferencial, sensível, crítico e libertário.

É nesse contexto que a questão "o que pode o cinema?" nos interessa, na medida em que se configura numa possibilidade de deslocar e pôr em suspensão este uso rotineiro e clichê que se tem feito do recurso cinematográfico em educação. Apresenta-se, assim, a questão-chave deste trabalho: o que pode o cinema, quando usado na educação, para além desta prisão didático-metodológica?

Para fazer frente a essa questão, organizamos o texto em seis seções. A primeira seção é um flash genealógico que pretende flagrar, no bojo da ética barroca, a emergência do modo singular de utilização das imagens visuais com propósitos didático-metodológicos, edificantes e moralizantes.

Retomando e respondendo a questão acerca do que pode o cinema, de modo a escapar da matriz didático-metodológica que, no Barroco, emerge como prisão discursiva, aparecem a segunda, terceira e quarta seções do texto. Elas tratam, respectivamente, de três usos diferenciais do cinema em educação, que podemos depreender da obra de Deleuze, mais especialmente de $A$ imagem-tempo (DELEUZE, 1990), quais sejam: uso transgressor para fazer "bem" pensar; uso visionário que faz devir o pensamento; uso problematizador da vida contemporânea.

É importante referir que esses usos diferenciais do cinema de que tratamos neste texto serviram como ponto de partida para duas atividades extensionistas que desenvolvemos, no decorrer do ano de 2011, junto ao Centro de Educação da Universidade Federal do Rio Grande do Norte $(\mathrm{UFRN})^{2}$. A partir da experimentação que fizemos desses três usos do

${ }^{2}$ Trata-se do projeto de extensão Cinema e educação: um olhar pós-estruturalista e do evento de extensão $1^{\circ}$ ciclo cinema, pensamento e educação, ambos coordenados pelos autores deste artigo. 
cinema nas atividades de extensão, as questões investigativas iniciais foram recolocando hipóteses e configurando novas possibilidades de estudo, o que culminou na constituição de dois projetos de pesquisa que passamos a desenvolver na UFRN ${ }^{3}$. Tanto as atividades de extensão quanto as de pesquisa, nas quais estamos envolvidos atualmente, fazem uso do cinema na educação, com o objetivo de cartografar a vida contemporânea, com foco nos modos de subjetivação da juventude contemporânea, a partir da decupagem de vivências, situações, enredos e personagens apresentados nos filmes, dentre os quais se destacam: Ken Park (Larry Clarck, EUA, 2002), Shortbus (John Cameron Mitchell, Estados Unidos, 2006), Elefante (Gus van Sant, EUA, 2003), A fita branca (Michael Haneke, Alemanha, Áustria, França, Itália, 2009), entre vários outros.

A quinta seção deste texto retoma, a partir de Deleuze (1990), e amplia, a partir de Arendt (2008), a tríplice função do cinema, para em seguida apresentar o resultado do trabalho que estamos realizando com Ken Park (Larry Clarck, EUA, 2002). Salientamos, também nessa quinta seção, os princípios metodológicos que orientam nosso trabalho cartográfico com os filmes, tais como aqueles referentes à atitude crítica, a partir de Foucault (2000), e à atitude intempestiva, a partir de Agamben (2009).

Para finalizar, e na intenção de divulgar os resultados preliminares do trabalho que estamos desenvolvendo com Ken Park, a sexta seção deste texto apresenta uma breve escrita cartográfica da contemporaneidade, produzida no encontro ${ }^{4}$ com Ken Park, mais especificamente, no encontro com os sujeitos contemporâneos deste filme: Como estão sendo

\footnotetext{
3 Trata-se dos projetos de pesquisa: Cinema e educação: o que pode o cinema? e Contemporaneidade e educação, ambos coordenados pelos autores deste artigo.

${ }^{4}$ Utilizamos aqui e doravante a noção de "encontro" pensada por Deleuze e Parnet (1998, p. 14-15): "um encontro é talvez a mesma coisa que um devir ou núpcias. [...] Ele designa um efeito, um ziguezague, algo que passa ou que se passa entre dois como sob uma diferença de potencial: ‘efeito Compton', 'efeito Kelvin'. Dizíamos a mesma coisa para os devires: não é termo que se torna outro, mas cada um encontra o outro, um único devir que não é comum aos dois, já que eles não têm nada a ver um com o outro, mas que está entre os dois, que tem sua própria direção, um bloco de devir, uma evolução a-paralela. É isso a dupla captura, a vespa E a orquídea: sequer algo que estaria em um, ou alguma coisa que estaria no outro, ainda que houvesse uma troca, uma mistura, mas alguma coisa que está entre os dois, fora dos dois, e que corre em outra direção". Daí que encontrar é = estar "entre" (de permeio); = ser interceptado pelo "fora" (exterioridade das relações); = devir (correr em outra direção); = evolução a-paralela; = dupla captura; = efeito Compton (quando um fóton de raios-X ou de raios gama muda de energia e de direção ao interagir com a matéria).
} 
constituídos, inventados, forjados? Quais suas singularidades, o que os afeta ou pelo que são afetados? Quais seus modos de viver? Quais seus valores e suas potências afirmativas? A que poderes, formas de dominação e práticas de liberdades estão sujeitados?

O final deste texto abre um leque de possibilidades porque, a partir da escrita cartográfica embalada por tais questões, outras tantas foram se recolocando, agora relativas à potência de um professor, de um curso, de uma disciplina, de uma aula. É por aí que pretendemos dar continuidade ao trabalho com os filmes, ou seja, após a ampliação dos temas analíticos aqui apresentados, e com a inclusão de outros filmes que inspirem a cartografia dos modos de subjetivação da juventude contemporânea, pretendemos interrogar: $\mathrm{O}$ que pode a educação frente aos sujeitos contemporâneos da educação? O que pode um professor? O que pode um curso? O que pode uma aula? - tudo isso fabricado ficcionalmente pelo encontro com os sujeitos contemporâneos dos filmes selecionados: é por onde pretendemos trabalhar futuramente...

\section{A emergência do uso didático das imagens visuais: a prisão barroca}

Em que contexto e com que finalidades emerge o uso utilitário, propagandístico e normalizador da imagem visual? Esta questão pretende, por meio de um flash genealógico, flagrar as associações e as conjunções - insuspeitas porque naturalizadas ao longo do tempo - entre a imagem visual e seu poder de persuasão. Em outras palavras: qual a emergência do uso doutrinário e moralizante das imagens visuais?

Santiago Sebastían e Werner Weisbach, duas importantes referências sobre o Barroco, evidenciam, na arte da contrarreforma, a emergência do uso propagandístico e doutrinador - e mais do que tudo: educativo e didático-metodológico - das imagens visuais.

É que o Barroco propõe uma finalidade retórica para artes visuais, aproveitando-se da fruição estética para conduzir a massa de fiéis, como evidencia Ceballos: "el arte cesaba de concebirse como un objeto de puro deleite estético, para convertirse en un formidable instrumento de propaganda orientado a la captación de las masas" (apud SEBASTÍAN, 1981, p. 10). 
Assim, a retórica - a arte de persuadir - passa a se projetar sobre os domínios da arquitetura e das artes plásticas, com ênfase na imagem visual. É o que expressa, em seu tratado teórico, o pintor Federico Zuccaro, primeiro presidente da Academia São Lucas em Roma: "nadie puede negar que un cuadro bien pintado mueve poderosamente la devoción y la disposición de ánimo, y que una historia pintada conmueve más que el mero relato de ella" (apud WEISBACH, 1948, p. 59).

Nos trechos citados, estão claros os sentidos atribuídos à imagem visual, cujo uso "move poderosamente a devoção e a disposição de ânimo", isto é, incita modos de ser e de agir, com efeitos coimplicadamente regulador e regulamentador. Diante disso, perguntamos: não se trata do mesmo efeito pretendido quando se usa o cinema para convocar determinados modos de ser, agir, se comportar frente aos saberes, ao ambiente, à saúde, às drogas, à realidade, ao mundo, etc.?

$\mathrm{O}$ investimento na capacidade propagandística e doutrinadora das artes plásticas e da arquitetura emergiu como a grande empresa do Barroco. Combatendo a atitude anti-imaginativa e a iconoclastia da Reforma, a arte da contrarreforma vai preconizar o uso da imagem visual, em maior grau até do que o uso da palavra escrita e falada. É justamente este uso da imagem visual como metáfora epistemológica do texto litúrgico que é recomendado pela vigésima quinta sessão do Concílio de Trento (1563):

Enseñen diligentemente los obispos que por medio de las historias de los misterios de nuestra redención, expresadas en pinturas y en otras imágenes, se instruye y confirma al pueblo en los artículos de la fe, que deben de ser recordados y meditados continuamente y que de todas las imágenes sagradas se saca gran fruto, no sólo porque recuerdan a los fieles los beneficios y dones que Jesucristo les ha concedido, sino también porque se ponen a la vista del pueblo los milagros que Dios ha obrado por medio de los santos y los ejemplos saludables de sus vidas (SEBASTÍAN, 1981, p. 62-63).

Aqui diretamente o que nos interessa: com o Barroco emerge o uso da imagem visual para ensinar, ou melhor, a imagem como o mais potente artifício propagandístico para "instruir", "fazer recordar" e tornar "alvo 
contínuo de meditação". Desde o século XVI, a imagem visual é alvo de uma constante modelagem dos modos de subjetivação, isto é, dos modos de ser e de se comportar dos sujeitos, em prol de uma ação tacitamente doutrinadora, que se investe de novas forças e de novas estratégias, tornando-se "instrução", "recordação" e "meditação contínua".

Embora algumas vezes com atravessamentos diversos, os fins atribuídos ao uso do cinema em educação reconstituem os objetivos com que a imagem visual passou a ser usada a partir do Barroco. Em educação, o cinema é quase tão-somente entendido e usado como metáfora, ou diretamente o veículo para o ensino-aprendizagem, ou ainda o recurso para a transposição didática de alguma coisa. Sempre a permanência do velho didatismo barroco do Concílio de Trento - a pedagogia e sua sempre fiel aliança com a moral dos padres admoestadores da consciência - o que credita à imagem um valor maior do que "mil palavras" (fórmula didática ainda consagrada pelos pedagogos na atualidade).

Lembremos, de passagem, que este valor didático da imagem visual, maior do que "mil palavras", vai produzir já no século XVII um discurso eminentemente pedagógico através da estratégia inventada pelo livro didático de Comenius que prevê o uso de imagens visuais como função "referente", "motivadora", metáfora da mensagem escrita e intermediadora da representação do mundo, como pontua Narodowski:

O livro de texto didático constrói uma estética que lhe é própria. Do ponto de vista da estrutura do conteúdo, o livro didático encarna uma transformação revolucionária que se funda na utilização da imagem. A imagem cumprirá a função de referente, bem como de motivadora. A imagem não apenas complementa o texto, como, ainda, é a protagonista da mensagem escrita, ao trazer à escola o mundo tal qual esse deve ser percebido. O livro didático representa o mundo com imagens (NARODOWSKI, 2001, p. 72).

Assim, quase quatrocentos anos depois, encontramo-nos presos à mesma matriz discursiva lançada nos séculos XVI e XVII: um uso - e um aprisionamento - da imagem visual, numa perspectiva didático-pedagógica voltada para a otimização do ensino-aprendizagem, também para conduzir, 
normalizar e corrigir condutas, com uma finalidade marcadamente moral e edificante - todos esses, diga-se de passagem, objetivos explícitos da Didática magna (COMENIUS, 2006), publicada pela primeira vez em 1657.

Mas o que pode o cinema para além deste uso dominante que vincula a imagem visual à normalização das condutas e/ou ao adestramento didático em prol do que, em Pedagogia, se chama de processos de ensinoaprendizagem?

Encontramos nas obras de Gilles Deleuze, sobretudo no capítulo $O$ pensamento e o cinema (DELEUZE, 1990), uma corrente de ar fresco que nos possibilitou pensar em outros horizontes para a questão "o que pode o cinema para a educação?”. Assim, com base em Deleuze, destacamos pelo menos três usos diferenciais do cinema em educação: 1) uso transgressor para fazer "bem" pensar; 2) uso visionário que faz devir o pensamento e 3) uso problematizador da vida contemporânea.

\section{Uso transgressor para fazer "bem" pensar}

Uma primeira ideia de um uso diferencial do cinema que se pode depreender de Deleuze, baseado, sobretudo, em Eisenstein, é a singularidade do cinema em produzir um choque no pensamento, e, assim, fazer pensar. ${ }^{5}$

\footnotetext{
${ }^{5}$ É uma aliança entre o choque produzido pela imagem-movimento e a ressonância dos harmônicos - imagem visual, sonora, texto escrito, etc., postos em circulação pelo cinema - que produz, para Deleuze, o efeito superlativo do cinema de fazer pensar pelo choque: "Há choque das imagens entre si segundo a dominante delas, ou choque na própria imagem segundo todos os seus componentes: o choque é a forma mesma da comunicação do movimento nas imagens. [...] o choque tem um efeito sobre o espírito, ele o força a pensar, e a pensar o Todo. O todo precisamente só pode ser pensado, pois é a representação indireta do tempo que decorre do movimento. Ele não decorre deste como um efeito lógico, analiticamente, mas sinteticamente, como o efeito dinâmico das imagens 'sobre o córtex inteiro'. [...] Já a imagem, visual ou sonora, tem harmônicos que acompanham a dominante sensível, e entram por conta própria em relações supra-sensoriais: é isso a onda de choque ou a vibração nervosa, tal que não se pode mais dizer 'vejo, ouço', mas SINTO, 'sensação totalmente fisiológica'. E é o conjunto dos harmônicos agindo sobre o córtex que faz nascer o pensamento, o PENSO cinematográfico" (DELEUZE, 1990, p. 191-192). Vejamos aqui que o "choque cinematográfico" que força a pensar não é só função da imagem-movimento, mas possui um forte componente do "sentir", comunicado pelos efeitos dos harmônicos disparados sobre nós pela linguagem cinematográfica.
} 
Este seria, aliás, o poder superlativo do cinema sobre as outras artes: ao colocar a imagem em movimento, ao fazer a imagem se movimentar sobre si mesma, o cinema nos força a pensar . Diz Deleuze (1990, p. 189-190):

É somente quando o movimento se torna automático que a essência artística da imagem se efetua: produzir um choque no pensamento, comunicar vibrações ao córtex, tocar diretamente o sistema nervoso e cerebral. Porque a própria imagem cinematográfica "faz" o movimento, porque ela faz o que as outras artes se contentam em exigir (ou em dizer), ela recolhe o essencial das outras artes, herda o essencial, é como o manual de uso das outras imagens, converte em potência o que ainda só era possibilidade. O movimento automático faz surgir em nós um autômato espiritual, que, por sua vez, reage sobre ele. $\mathrm{O}$ autômato espiritual já não designa, como na filosofia clássica, a possibilidade lógica ou abstrata de deduzir formalmente os pensamentos uns dos outros, mas o circuito no qual eles entram com a imagem-movimento a potência comum do que força a pensar e do que pensa sob o choque: um noochoque Heidegger dirá: "o homem sabe pensar na medida em que tem a possibilidade de pensar, mas esse possível ainda não garante que sejamos capazes de pensar". É essa capacidade, essa potência, e não a mera possibilidade lógica que o cinema pretende nos dar comunicando-nos o choque. Tudo se passa como se o cinema nos dissesse: comigo, com a imagem-movimento, vocês não podem escapar do choque que desperta o pensador em vocês. Um autômato subjetivo e coletivo para um movimento automático: a arte das "massas".

Fazer pensar, obrigar a pensar, coagir a pensar - boas funções para o uso do cinema. Produzir um choque no pensamento, um noochoque eis algo que vai driblar a função de adestramento didático e moral, que se desvela pelo uso corriqueiro do cinema em educação. Ao invés de doutrinar, abalar; ao invés de adestrar, violentar: o cinema como abalo e violência ao pensamento.

Mas para que se compreenda a potência do que significa dizer que o cinema "força a pensar", é preciso considerar que, para Deleuze, o ato de pensar não é um ato gratuito, fortuito, corrente, banal, corriqueiro, natural, 
casual, espontâneo ou acidental. Ao contrário disso, na conferência $O$ ato de criação, Deleuze (1999) vai dizer que ter uma ideia, pensar ou mais propriamente fabricar um pensamento é um evento raro, improvável e difícil, é algo produzido e forçado pela necessidade de inventar, fabricar, criar, forjar um conceito, cuja razão de ser remete não a algo genérico, mas a um problema concreto, cuja necessidade e urgência nos força a pensar.

Adotando um ceticismo sobre a ideia de que nós pensamos, Deleuze fará da radicalidade da afirmação heideggeriana, a principal evidência da extrema dificuldade do ato de pensar. Trata-se da afirmação inúmeras vezes repetida no texto $O$ que quer dizer pensar? de Heidegger (2006, p. 115) : "o que mais cabe pensar cuidadosamente em nosso tempo, que tanto nos dá a pensar, revela-se no fato de ainda não pensarmos". Assim, é considerando esta quase impossibilidade do ato de pensar que o cinema, na perspectiva deleuziana, se torna um agente privilegiado da experimentação do pensamento, em prol de um pensamento diferencial.

Pelos motivos expostos da dificuldade do ato de pensar, é claro que Deleuze também verá com ceticismo o poder do cinema em nos fazer pensar pela produção de um noochoque. Para ele, as provas cabais de que o cinema não nos fez pensar é o fato de o mundo e os homens não terem mudado e, o que é até mais grave, o fato de o próprio cinema ter caído nas mãos da propaganda e da manipulação do Estado, de modo que a função do cinema foi adestrar e doutrinar, mais do que abalar e violentar o pensamento.

Agindo mais cautelosamente em relação à produção de pensamentos por decorrência do noochoque, Deleuze vai lançar mão dos argumentos de Artaud, que deslocam a questão do choque do pensamento produzido pelo cinema, para flagrar e problematizar a própria incapacidade de pensar. Assim, para Artaud, o cinema não produz pensamento, mas produz um choque que evidencia a impotência do pensamento para pensar, isto é, o fato hideggeriano de que nós não pensamos, o fato de que o nosso pensamento está obstruído, imobilizado, aprisionado. Nas palavras de Deleuze:

Dir-se-ia que Artaud vira pelo avesso o argumento de Eisenstein: se é verdade que o pensamento depende de um choque que o faz nascer, ele só pode pensar uma única coisa, o fato de que ainda não pensamos, 
a impotência tanto para pensar o todo como para pensar a si mesmo, estando o pensamento sempre petrificado, deslocado, desabado. Um ser do pensamento sempre por vir, é o que Heidegger descobrirá sob uma forma universal, mas é também o que Artaud já viveu como o problema mais singular, seu próprio problema. De Heidegger a Artaud, Maurice Blanchot sabe ler em Artaud a questão fundamental do que faz pensar, do que força pensar: o que força pensar é o "impoder do pensamento", a figura do nada, a inexistência de um todo que pudesse ser pensado. O que Blanchot diagnostica por toda a parte na literatura vamos encontrar em lugar de destaque no cinema: por um lado a presença de um impensável no pensamento, e que seria a um só tempo como que sua fonte e sua barragem. [...] A ruptura sensório motora faz do homem um vidente que é surpreendido por algo intolerável no mundo, e confrontado com algo impensável no pensamento. Entre os dois, o pensamento sofre uma estranha petrificação que é como que sua impotência de funcionar, de ser, como que ser despossuído de si mesmo e do mundo (DELEUZE, 1990, p. 202-203; 205).

À luz do que nos expõe Deleuze, a partir de Artaud, o cinema pode flagrar a impossibilidade do ato de pensar. Daí um uso profícuo do cinema que, a partir do choque ou da violência, não nos conduziria ao ato de pensar, mas nos exporia à fragilidade do nosso pensamento sobre as coisas, à nossa debilidade enquanto sujeitos pensantes; o cinema como produção do insuportável porque é golpe certeiro à nossa tão aclamada faculdade superior: a razão. Aqui, a potência da sétima arte em nos conduzir à insuportável desilusão: nós pensamos que pensamos; somos cegos repetidores do já representado/pensado.

\section{Uso visionário que faz devir o pensamento}

Assinalada a primeira potencialidade de "o que pode o cinema?", na contramão de adestrar saberes e normalizar condutas, uma segunda função que poderíamos abstrair de uma perspectiva deleuziana do cinema é o seu poder de resistência, poder este, segundo Deleuze (1999), não só do cinema, mas da arte de um modo geral. De que resistência se trata? 
Na conferência $O$ ato de criação, Deleuze (1999) dirá que a relação entre $\mathrm{o}$ ato de resistência e a obra de arte reside no fato de a arte resistir à morte: daí seu devir revolucionário. Em outro momento naquela mesma conferência, Deleuze recupera uma expressão dita por Paul Klee - "falta o povo" - para afirmar que a arte tem um devir revolucionário ao criar um povo que falta; diz Deleuze: "não existe obra de arte que não faça apelo a um povo que não existe".

É o que explica detalhadamente Roberto Machado, analisando esta concepção de Deleuze da obra de arte como criadora de um povo por vir:

Retomando uma afirmação de Paul Klee - "falta o povo" -, que estende a Mallarmé, Rimbaud, Berg, Straub, Deleuze complementa essa ideia defendendo a afinidade entre a obra de arte e um povo que ainda não existe, ou defendendo que não há obra de arte que não apele para um povo que ainda não existe. A função da literatura menor é contribuir não para representar, mas para inventar, criar um povo, um povo que falta; não um povo destinado a dominar, mas um povo menor, uma minoria criadora, um povo tomado num devir revolucionário, ou como Deleuze também diz, "bastardo, inferior, dominado, sempre em devir, sempre inacabado". Se o escritor torce a linguagem e cria perceptos e afetos, é tendo em vista o povo que ainda falta (MACHADO, 2010, p. 216)

Por deslocar e por fabricar uma representação diferencial, a obra de arte cria e inventa um povo por vir, um povo que não existe; daí sua função visionária. Isso faz com que outra resposta possível para a questão "o que pode o cinema?" seja uma função de resistência e de vidência, criadora de uma realidade impensada e impensável, e que por isso nos faz fugir dos modelos, dos estereótipos e dos clichês, em prol de um "povo menor", de um devir minoritário que transgride o dominantemente representado/ pensado.

Em outras palavras: aproveitando-nos destas ideias de Deleuze, defenderemos aqui um segundo uso potente do cinema em educação, uma função ao mesmo tempo de vidência e de resistência, porque ao apresentar um mundo ou um universo impensável - aquele em que "falta o povo" - o cinema pode abrir brechas e fissuras nas representações que nos impedem 
de pensar, já que percebemos e pensamos somente o normal representado ou representável.

\section{Uso problematizador da vida contemporânea}

Uma terceira função do cinema que se pode depreender de Deleuze refere-se a um compromisso inolvidável com o presente, isto é, um poder do cinema em presentificar e em exibir as formas e os modos de ser e de viver contemporâneos, o que, por se encontrarem identificados à própria existência dos sujeitos viventes, passam despercebidos ou são imperceptíveis.

Trata-se, neste caso, de um uso do cinema para nos fazer crer neste mundo, que vá à superficialidade dos modos de vida contemporâneos, para expor o que é duplamente vigente e modelizante, o que diagramaticamente configura os modos de subjetivação da vida atualmente vivida. Nas palavras de Deleuze, o cinema como restituidor da crença neste mundo, como condição de possibilidade de percebermos o que nos passa, o que nós nos tornamos e, também, aquilo que nós estamos nos tornando:

O fato moderno é que não acreditamos nesse mundo. Nem mesmo nos acontecimentos que nos acontecem, o amor, a morte, como se nos dissessem respeito apenas pela metade. [...] Somente a crença no mundo pode religar o homem com o que ele vê e ouve. É preciso que o cinema filme, não o mundo, mas a crença neste mundo, nosso único vínculo. Repetidas vezes já se perguntou qual a natureza da ilusão cinematográfica. Restituir-nos a crença no mundo: é este o poder do cinema moderno (quando deixa de ser ruim). Cristãos ou ateus, em nossa universal esquizofrenia precisamos de razões para crer neste mundo. É toda uma conversão da crença. Já foi uma grande guinada da filosofia, de Pascal a Nietzsche: substituir o modelo do saber pela crença. Porém, a crença substitui o saber tão-somente quando se faz crença neste mundo, tal como ele é (DELEUZE, 1990, p. 207-208).

Crer no mundo tal como ele é: o cinema como tática e estratégia para surfar na superfície do contemporâneo, dissolvendo as esquivas que desenvolvemos para nos proteger do que nos é desagradável, inaceitável e 
insuportável - o cinema justamente como experimentação do radical, do insuportável e do intolerável da vida atualmente vivida.

Neste terceiro uso, o cinema possibilitaria problematizar a contemporaneidade, incitando a produção de cartografias do presente disparadas pelo efeito-choque de narrativas fílmicas cujos focos se circunscrevessem ao redor das questões: "o que estamos fazendo de nós hoje?", “o que é que nós nos tornamos?”, “o que é que estamos nos tornando?" - questões-chave para problematização de "o que é isso a que chamamos de contemporaneidade/atualidade?".

Este último uso do cinema orienta-se, com base em Deleuze e Guattari (1996), na ferramenta de investigação conhecida como cartografia: não propriamente um método, mas uma espécie de sensibilidade de pesquisa adaptável e mutante que flagra as relações de forças - sempre imanentes, instáveis, dinâmicas e múltiplas - que compõem um campo específico de experiências.

No trabalho de pesquisa que vimos desenvolvendo, entendemos que cartografar a atualidade não significa desenhar um mapa fixo ou histórico da contemporaneidade, mas - a partir do estabelecimento de encontros com o mundo, mediados por determinados filmes - traçar as linhas que configuram uma espécie de diagrama de possibilidades, de fluxos e de devires que estão em jogo em um acontecimento singular da vida vivida pelas personagens. Um desenho difícil de ser traçado na medida em que ao cartógrafo interessam os acidentes, as singularidades, as mutações, os agenciamentos, as densidades, as intensidades, as efemeridades e as transitoriedades - os "fluxos de quanta", diriam Deleuze e Guattari (1996, p. 99):

Um fluxo mutante implica sempre algo que tende a escapar aos códigos não sendo, pois, capturado, e a evadir-se dos códigos, quando capturado; e os quanta são precisamente signos ou graus de desterritorialização no fluxo descodificado.

\section{Afinal, o que pode o cinema para a educação?}

Retomando o que vimos desenvolvendo no texto até aqui, temos que, para escapar à função ilustrativa, metafórica, didático-pedagógica, normalizante e moralizante, dominantes nos usos rotineiros do cinema 
em educação, destacam-se três funções diferenciais do cinema, que depreendemos de Deleuze, e que sumariamos a seguir:

1) O cinema como produtor de choques e violências ao pensamento, flagrando sua estagnação, imobilidade e inércia, possibilitando o uso do cinema na experimentação do pensamento (uso transgressor para fazer "bem" pensar);

2) $\mathrm{O}$ cinema como vidência e resistência às representações dominantes e aos clichês, abrindo a percepção ao campo de experimentação do não representado e do imperceptível (uso visionário que faz devir o pensamento);

3) O cinema como recurso privilegiado para uma cartografia do tempo presente, permitindo flagrar o contemporâneo em sua potência afirmativa, sem ressalvas (uso problematizador da vida contemporânea).

Para complementar essas três funções que passamos a atribuir ao cinema para pensar e pesquisar o campo da educação, encontramos na obra de Hannah Arendt - intitulada Eichmann em Jerusalém: um relato sobre a banalidade do mal - um interessante argumento para defender uma função educativa do cinema, enquanto condição de possibilidade de fazer pensar, de explodir e implodir as representações estereotipadas e os clichês.

Nesta obra, em que a autora documenta e analisa o julgamento de um dos maiores homens de poder do Terceiro Reich, o responsável pela deportação dos judeus, e, mais tarde, o encarregado da solução final, isto é, do envio dos judeus para os campos de concentração, o que percebe Arendt? Que as atitudes monstruosas de Eichmann são produto de sua incapacidade de pensar - é a impossibilidade de pensar diferente do oficialês, do discurso instituído e dominante e do clichê que tornam Eichmann um escravo servil e obediente aos mandos do Reich. Vejamos a belíssima análise da autora:

Vagamente consciente de uma incapacidade que deve tê-lo perseguido ainda na escola - chegava a ser um caso brando de afasia - ele [Eichmann] pediu desculpas dizendo: "Minha única língua é o oficialês [Amtssprache]". Mas a questão é que o oficialês se transformou em sua única língua porque ele sempre foi genuinamente incapaz de 
pronunciar uma única frase que não fosse um clichê. [...] Sem dúvida, os juízes tinham razão quando disseram ao acusado que tudo o que dissera era "conversa vazia" - só que eles pensaram que o vazio era fingido, e que o acusado queria encobrir outros pensamentos que, embora hediondos, não seriam vazios. Essa idéia parece ter sido refutada pela incrível coerência com que Eichmann, apesar de sua má memória, repetia palavra por palavra as mesmas frases feitas e clichês semi-inventados (quando conseguia fazer uma frase própria, ele a repetia até transformá-la em clichê) toda vez que se referia a um incidente ou acontecimento que achava importante. Quer estivesse escrevendo suas memórias na Argentina ou em Jerusalém, quer falando com o interrogador policial ou com a corte, o que ele dizia era sempre a mesma coisa, expressa com as mesmas palavras. Quanto mais se ouvia Eichmann, mais óbvio ficava que sua incapacidade de falar estava intimamente relacionada com sua incapacidade de pensar, ou seja, de pensar do ponto de vista de outra pessoa. Não era possível nenhuma comunicação com ele, não porque mentia, mas porque se cercava do mais confiável de todos os guarda-costas contra as palavras e a presença dos outros, e portanto contra a realidade enquanto tal (ARENDT, 2008, p. 61-62).

Ter o oficialês como língua; viver, como na fábrica, sob uma linha padronizada e mecânica de produção discursiva; repetir e transformar tudo em clichês - Eichmann não tem condição de possibilidade para pensar eis aí a banalidade do mal: a prisão discursiva criando a (e sendo criada pela) impossibilidade de pensar. Discurso padronizado $=$ sem pensamento $=$ mal (para não dizer $=$ nazismo). $\mathrm{Ou}$, como propõe a digressão de Arendt: "oficialês" $\leftrightarrow$ sem pensamento $\leftrightarrow$ sem alteridade $\leftrightarrow$ negação da realidade $\leftrightarrow$ banalidade do mal.

A referência que fazemos a Arendt se vincula à tríplice função do cinema de que tratamos neste texto a partir de Deleuze, na medida em que os três usos a que o cinema se presta (transgredir, resistir e problematizar) podem ser potentes para enfrentar a guerra da educação contra o "mal" com novas armas, talvez um pouco mais táticas e estratégicas.

Trata-se aqui, parafraseando Adorno (2003, p. 119), de pensar numa educação "para que Auschwitz não se repita" - exigência primeira 
para a educação, como ressalta Adorno - através de um uso do cinema que nos obrigue, que nos force, que nos pressione a pensar, ou que nos mostre radicalmente que nós não pensamos; através de um uso do cinema visionário e vidente, que resiste ao representado, ao dominante, ao estereótipo e ao clichê; através de um uso do cinema problematizador dos modos de viver contemporâneos, que nos permita cartografá-los e, assim, nos faça perceber e pensar nas formas de dominação da vida vivida na atualidade.

Esta tríplice aliança contra as banalidades do mal ou "para que Auschwitz não se repita” está no esteio do que Xavier (2008, p. 15) sugere como a função capital do cinema para a educação:

Para mim, o cinema que "educa" é o cinema que faz pensar [...]. A questão não é "passar conteúdos", mas provocar a reflexão, questionar o que, sendo um constructo que tem história, é tomado como natureza, dado inquestionável.

Tomando como hipótese de pesquisa, os referidos usos diferenciais do cinema, um dos filmes com o qual estamos trabalhando atualmente nos referidos projetos de pesquisa e extensão vinculados à Universidade Federal do Rio Grande do Norte - é Ken Park (Larry Clarck, EUA, 2002). A partir da decupagem das vivências, das situações, dos enredos e dos personagens apresentados por esta narrativa fílmica, pretendemos cartografar os sujeitos contemporâneos da educação.

Nesse sentido, a escolha deste filme se deu por sua potência em inspirar a problematização desses sujeitos, tendo por efeito principal a condução do expectador/pesquisador a um choque/abalo da moral e do pensamento, possibilitando flagrar a vida contemporânea em sua potência afirmativa, sem ressalvas, ressentimentos ou saudosismos em relação ao tempo pregresso.

Ressalve-se que esta força afirmativa da cartografia dos sujeitos contemporâneos que estamos realizando com Ken Park é enviesada, obrigatoriamente, por uma "atitude crítica" em relação ao próprio tempo contemporâneo, isto é, como maneira de desconfiar, limitar, recusar, 
deslocar, escapar de seus ditames e governos ${ }^{6}$.

Para circunstanciar esta atitude crítica em relação ao tempo presente, que se evidencia marcadamente em nossa escrita cartográfica mediada por Ken Park, recorremos ao que Giorgio Agamben, em seu ensaio $O$ que é o contemporâneo?, vai chamar de "atitude intempestiva". Invocando as Considerações intempestivas de Nietzsche, diz o autor:

Em 1874, Friedrich Nietzsche, um jovem filólogo que tinha trabalhado até então sobre textos gregos e, dois anos antes, havia atingido uma inesperada celebridade com $\mathrm{O}$ nascimento da tragédia, publica as Unzeitgemässe Betrachtungen, as "Considerações intempestivas", com as quais quer acertar as contas com o seu tempo, tomar posição em relação ao presente. "Intempestiva esta consideração o é", lê-se no início da segunda "Consideração", "porque procura compreender como um mal, um inconveniente e um defeito algo do qual a época justamente se orgulha [...]". Nietzsche situa a sua exigência de "atualidade", a sua "contemporaneidade" em relação ao presente, numa desconexão e numa dissociação. Pertence verdadeiramente ao seu tempo, é verdadeiramente contemporâneo, aquele que não coincide perfeitamente com este, nem está adequado às suas pretensões e é, portanto, nesse sentido, inatual; mas, exatamente por isso, exatamente através desse deslocamento e desse anacronismo, ele é capaz, mais do que os outros, de perceber e aprender o seu tempo (AGAMBEN, 2009, p. 58-59).

\footnotetext{
${ }^{6}$ Referimo-nos aqui à noção de "atitude crítica" desenvolvida por Michel Foucault, que encontra sua elaboração mais precisa na conferência $O$ que é a crítica?, proferida por Foucault na Société Française de Philosophie, em 27 de maio de 1978: "Em face, e como contraparte, ou melhor, como parceira e adversária das artes de governar, como maneira de desconfiar delas, de recusá-las, de limitá-las, de lhes encontrar uma justa medida, de transformá-las, de procurar escapar a estas artes de governar, ou, em todo caso, de deslocálas a título de reticência essencial, [...] teria nascido na Europa, naquele momento, uma espécie de forma cultural geral, ao mesmo tempo, atitude moral e política, maneira de pensar etc., que pode ser chamada como arte de não ser governado ou arte de não ser governado dessa forma e a esse preço. Proporia, portanto, como uma primeira definição da crítica, esta caracterização geral: a arte de não ser de tal forma governado" (FOUCAULT, 2000, p.172).
} 
Foi por este poder de Ken Park em incitar, deflagrar, disparar e criar em nós uma atitude intempestiva, que iniciamos por este filme a escrita do que chamamos de cartografia dos sujeitos contemporâneos - um projeto eminentemente ético-político, no sentido da atitude intempestiva que comporta e produz. Com isso, reafirmamos o fator que possibilita a escrita desta cartografia: o cinema como violentador, que força e que cria a necessidade, o interesse e o desejo pela escrita cartográfica ${ }^{7}$.

Daí, dois princípios metodológicos: primeiro, a intempestividade é preciso que algo nos perturbe, que seja intolerável, que seja insuportável; é preciso que algo nos afete muito, que violente nossos modos de pensar e agir - é preciso que algo nos coloque, paradoxalmente, "junto" e "fora" do nosso tempo - tudo isso para que a ideia e o desejo da escrita cartográfica nos ocorram.

Segundo princípio metodológico é a força do "entre", na acepção de Deleuze e Parnet (1998, p. 29, grifo dos autores): "O que define [a multiplicidade] é o E, como alguma coisa que ocorre entre os elementos ou entre os conjuntos. E, E, E”. Daí o cinema como tática que deflagra, incita e possibilita uma escrita "entre" (e não "sobre"): "entre" os personagens, "entre" as situações, "entre" os enredos, "entre" as cenas, "entre" os diálogos, "entre" as afecções vividas, "entre" as violências sofridas, "entre" o insuportável vivenciado, "entre" as provocações, as inquietações e os estranhamentos experimentados, "entre" as emoções, devires e fluxos sentidos, etc.

\footnotetext{
${ }^{7}$ O projeto de uma escrita cartográfica, conforme a acepção aqui utilizada, pressupõe a concepção de escritura como atitude crítica e ético-política, tal como foi pensada por Deleuze e Parnet (1998, p. 56): "Escrever é traçar linhas de fuga, que não são imaginárias, que se é forçado a seguir, porque a escritura nos engaja nelas, na realidade, nos embarca nela. Escrever é tornar-se [...]. Bem diferentes são os devires contidos na escritura quando ela não se alia a palavras de ordem estabelecidas, mas traça linhas de fuga. Dir-se-ia que a escritura, por si mesma, quando ela não é oficial, encontra inevitavelmente "minorias", que não escrevem, necessariamente, por sua conta, sobre as quais, tampouco, se escreve, no sentido em que seriam tomadas por objeto, mas, em compensação, nas quais se é capturado, quer queira, quer não, pelo fato de se escrever. Uma minoria nunca existe pronta, ela só se constitui sobre linhas de fuga que são tanto maneiras de avançar quanto de atacar". Complementarmente, em outra obra, Deleuze vai pontuar uma tripla definição do ato de escrever, que afirma os sentidos da escritura que queremos assinalar neste artigo: "escrever é lutar, resistir; escrever é devir; escrever é cartografar” (DELEUZE, 2005, p. 65).
} 
Enfim, quando dizemos que estamos realizando uma cartografia dos sujeitos contemporâneos, disparada por Ken Park, do que se trata? Trata-se de forjar encontros entre um projeto de escrita, o cinema e a contemporaneidade interpelada pelo viés dos modos de subjetivação, considerando o uso do cinema como condição de possibilidade de criação de um traçado diagramático das linhas de força que configuram os sujeitos contemporâneos: Como estão sendo constituídos, inventados, forjados? O que a juventude contemporânea está se tornando, quais os seus movimentos e fluxos? O que fazem de suas vidas? Quais as suas singularidades, o que os afeta ou pelo que são afetados? Quais os seus modos de viver? Quais os valores e as potências afirmativas desta juventude contemporânea? A que poderes, formas de dominação e práticas de liberdades estes sujeitos contemporâneos estão sujeitados? Quais linhas de fuga estão sendo e/ou podem ser inventadas e criadas?

$\mathrm{Na}$ intenção de corporificar nossa afirmação de que o cinema pode ter efeito potencializador do pensamento e da escrita, apresentamos, a seguir, na última parte deste texto, uma breve escrita cartográfica dos sujeitos contemporâneos, produzida com Ken Park. É o resultado de um recente primeiro encontro com os sujeitos contemporâneos de Ken Park; cada um dos seus personagens, em suas singularidades: Tate, Claude, Shawn, Peaches, o próprio Ken ...

\section{O que pode o cinema para a educação? Uma possível cartografia dos sujeitos contemporâneos com Ken Park ...}

A vida sobre as rodas do skate. Movimento, manobras radicais, o mundo passa, tudo é fluxo. Rapidez, velocidade. Um estranho sorriso para morte, alívio? Quando viver ou morrer é questão de instante, decisão de instante: passionalidade. Os instantes são eternos, não há história ou memória nos personagens. Eles são atualíssimos, bebem da imanência do instante. De repente, a faca que corta o bolo; num instante depois, o punhal do assassino. Antes, um "bolo de creme Boston com cobertura de marasquino e cerejas"; dois minutos depois, o sangue esguichado no rosto. Nada prepara a cena, apenas o agenciamento "ir à cozinha - comer bolo 
- passar em frente à porta do escritório do avô - lembrar da trapaça esfaquear". No filme tudo é agenciamento imediatista ao máximo. Daí uma sensação de violência prolongada, sustenida, condensada, como se algo fosse acontecer. Tudo acontece e nada se prevê; tudo continua acontecendo e não sabemos nunca dizer onde as coisas irão dar, surpresa renovada, máxima imprevisibilidade.

Ao mesmo tempo, tudo é banal. Nenhum preparo, nenhum ritual, nenhuma demora, nenhuma dúvida, como se as coisas se encadeassem a serviço de um "ser" desejante que perdeu o leme, que está à deriva. Tudo flutua como o devir-insanidade que sentimos dos personagens. Nem o suicídio é premeditado, nada prepara o suicídio de Ken Park. Não somos avisados, não há indícios, nada se sugere... E de repente o tiro, como se tudo fosse agenciado no instante, no agora, no já. Poderia não ser aquele o dia - isso não faria diferença, nada faz muita diferença, tudo é fluxo de desejos, de emoção, de sensação e a vida daqueles personagens é sempre alucinógena, delirante, louca. Afinal, sucumbimos à prisão dos prazeres? Há um Eros sedutor que a tudo engaja, forja de subjetividades sedutoras e seduzidas, como se viver fosse viver em risco. Daí que o valor da vida é um sorriso por um novo prazer, mesmo à custa de um tiro que transpasse a cabeça; isso tão-somente.

Lembremos... É um dia como outro qualquer, skate rolando, som delirante às alturas, velocidade, fluxo, manobras radicais. Mais um dia qualquer em Vesalia com Ken a caminho de uma pista de skatistas. Ondas, o mundo como altos e baixos que se sucedem e nada querem dizer, como se a velocidade de tudo fosse rápida demais para deixar marcas. Os personagens são arrastados pela banalidade dos fluxos, das rapidezas, tais quais os desejos que vão e vêm, nascem e se esgotam, tudo passa, nada dura. Não há tempo para que nada se cristalize, nada se solidifica, nada continua; tudo é revolução, saltos quânticos, imprevisibilidade. Os fluxos, os fluxos, a vida sobre ondas, a pista de skate como um instante que passa, que se presentifica no instante em que passa, que não deixa rastros, que não prenuncia futuridades. $\mathrm{O}$ depois e o antes são sempre movimentos do agora: o resto é vácuo, é vazio, é nada; inexistência e atemporalidade. Um suicida totalmente insuspeito, sua câmera de filmagem e, de repente, um revólver... E o dia corre normalíssimo, nada se destinge, nada é diferente, 
homogeneidade do tempo-espaço, nada estranha, nada precipita, nada se insinua. O gesto, apenas o gesto de ir seguindo o fluxo dos desejos, fluxos fugazes e totalizantes, a vida como imanência dos fluxos desejantes, nada mais. Depois, tudo se esvai, tudo se esvaece, nem o tiro, nem a violência, nem o sangue destilante perturbam a cadência dos instantes que seguem refluxantes. Ken Park é narrado num jogo cuja única regra é o esquecimento. Nenhum ressentimento, nenhuma dor, nenhum sofrimento, nenhuma culpa.

Em Ken Park tudo acontece, tudo se perde, não há memória: garantias de experimentação máxima, de máximo desejo, de máximo prazer. Tudo é simulacro, tudo é fake, tudo é fantasia, tudo é delírio, tudo é experimentação ativa, tudo é instante, fluxo-desejo. A vida como instante, sem historicidade, nem começo, nem fim. Tampouco há meio, porque não há sequência, enredo previsível, tudo é acontecimento, imanência, singularidade e instante.

Assim, para o personagem Tate, no meio tempo entre o assassinato dos avós e a confissão do crime diante de um gravador, apenas mais uma ereção passageira, atropelada pelo latido do cachorro "legs" (pernas). A temporalidade dos personagens está impregnada deste tempo da ereção, do gozo, acontecimento puro, duração indeterminada, fé no desfrute de cada instante que passa, nenhuma promessa, nenhuma dívida, nenhum a priori e nenhum depois. Na vida da sociedade sobre as ondas do skate, o prazer é instante, o sujeito desejante é instante, a vida é experimentação do instante. A fórmula é simples: quanto mais instante, mais vida, mais potência de experimentação da vida, ainda que a experimentação trame contra a vida, seu valor é a do risco maior que leve a outra gozada, efêmera, única e total. O gozo reinventado e transbordante como estética da vida, que gira na velocidade das rodas do skate.

Esta estética da vida ancorada na potência e na intensidade do gozo põe em cena os personagens como sujeitos do desejo: nada os detém, a vida é esfacelamento de fluxos e refluxos de desejos instantâneos que afloram da superfície, tomam os personagens e decidem o acontecimento da cena. Nenhuma ética, nenhuma renúncia. A razão de existir é ser um vencedor: a competição dinamizando os desejos, produzindo desejos, propiciando 
as capturas. De resto, nenhuma utopia, nenhum sonho; amnésia. A vida capturada pelo prazer - o prazer de si, em si, para si: Eu onipresente e onipotente.

Um casal de velhos se beija depois de uma partida de tênis, dizendo um ao outro: "eu te amo". Durante o jogo, o foco na decadência e na decrepitude: a feiúra da pele enrugada, a debilidade dos gestos... Sinais de que o tempo do "eu te amo" findou, indícios explícitos da obsolescência das declarações de amor. A cena que se segue foca, na televisão do quarto de Tate, outra partida de tênis. Deste lado, a vida é manifestação gasosa e frágil. Sob a tela da tela, uma tenista jovem e forte. A tigresa duela com o casal de decrépitos (avós de Tate). Então, movido pela irrupção de um momentâneo tesão, Tate é desejo e risco, Eros e Tânatos, risco potencializando o desejo, desejo potencializando o risco. Aqui tudo é táctil, epiderme, sinergismo, curto circuito, explosão. Tudo é geração e aniquilação, instantâneas.

Tate espera dos velhos que não trapaceiem no jogo, ele quer regra, quer exemplo. Não roubar no jogo, não mentir - eis a lei do Talião imposta por Tate. Sob o risco de que, não obedecendo à lei, os avós merecem morrer. Em Ken Park, as famílias estão esfaceladas, ninguém é exemplo, ninguém renuncia aos prazeres, a ética não é o cuidado do outro, a solidariedade com o outro, a generosidade para como o outro. A estética da existência em Ken Park é o império dos desejos e a total liberdade individual para desejar. O hiperindividualismo quer e requer o hiperdesejo.

A mãe, mas, sobretudo, o pai de Claude, deseja o filho. O pai de Peaches, emblema do ortodoxo religioso, quer a filha. Nem o fundamentalismo do pai de Peaches o liberta do império dos desejos, curiosa inversão, porque, diante daquele blefe, diante daquela farsa, ficamos sem chão. Esperávamos nós, curioso absurdo, que, por via do fundamentalismo, viria "contenção de si", "domínio de si"? Sim, esperávamos, mas nada advém com a narrativa do filme. Trata-se de um pai que é puro desejo e prazer, tão inebriado como os outros meninos.

O estranho em Ken Park é que até o fundamentalismo é farsa, é que até os fundamentalistas sucumbiram, assim como os seus inimigos, os infiéis e os impuros, à consumição, à concupiscência, ao prazer. Do outro lado, a mãe de Claude grávida, sempre meio embriagada, fumante 
inveterada, dá a experimentar ao seu bebê, precocemente, os efeitos das drogas. Os personagens são individualistas demais, desejosos demais para renunciar a qualquer coisa que lhes subtraia, adie ou desacelere a experimentação do prazer. Escravos de si, eles vivem em perpétua errância, como se a vida fosse só aquilo: fluxos de prazeres, satisfação individual, consumo do outro para o prazer de si.

Vivemos em Ken Park a generalização do "sujeito desejante", um novo modo de "ser", uma nova estética da existência acionada por uma irresistível e irrecusável sensação nova a experimentar; vive-se pelas intensidades-riscos, em comunhão com Eros-Tânatos; vive-se de uma liquidez passional em extrema frieza e apatia, porque o menor contato é contágio que põe em risco o livre experimentar. Talvez Ken Park nos exponha, não sem crueldade, a onipotência dos fluxos desejantes de um "eu" onipresente, que alimenta e é alimentado por nossa vida contemporânea.

Assim, tal como em Ken Park, vivemos subjetivados pela velocidade de fluxos que irrompem, aprisionados em fazer da vida, sensações; outorgamo-nos, mais do que tudo, uma genuína liberdade do "eu" para experimentar; aprendemos que o melhor consumo vem do prazer instantâneo que diariamente exigimos das nossas pretensamente "intensas" vidas. Seguimos, assim, com Ken Park, sob os fluxos de uma reafirmada liberdade de viver e de experimentar que não nos deixa desconfiar que o que chamamos de homem livre é algo infinitamente mais ingênuo, mais servil e mais covarde que o sorriso que vai engatilhar o tiro do revólver.

\section{Referências}

ADORNO, Theodor W. Educação após Auschwitz. In: . Educação e emancipação. São Paulo: Paz e Terra, 2003. p. 119-138.

AGAMBEN, Giorgio. O que é o contemporâneo? E outros ensaios. Chapecó: Argos, 2009.

ARENDT, Hannah. Eichmann em Jerusalém: um relato sobre a banalidade do mal. São Paulo: Companhia das Letras, 2008.

COMENIUS. Didática magna. São Paulo: Martins Fontes, 2006.

DELEUZE, Gilles. A imagem-tempo. São Paulo: Brasiliense, 1990. 
. O ato de criação. Folha de São Paulo 27 Jun. 1999. Disponível em: <http://www.youtube.com/watch?v $=$ GYGbL5tyi-E $>$. Acessado em: 11 mar. 2011.

. Foucault. Lisboa: Edições 70, 2005.

; GUATTARI, Félix. Mil platôs: capitalismo e esquizofrenia. v. 3. São Paulo: 34, 1996.

; PARNET, Claire. Diálogos. São Paulo: Escuta, 1998.

FOCAULT, Michel. O que é a crítica? (Crítica e Aufklärung). Marília: Cadernos da Faculdade de Filosofia e Ciências/UNESP Marília, v. 9, n. 1, p. 169-189, 2000.

HEIDEGGER, Martin. O que quer dizer pensar? In: . Ensaios e conferências. Petrópolis: Vozes, 2006. p. 111-124.

MACHADO, Roberto. Deleuze, a arte e a filosofia. Rio de Janeiro: Jorge Zahar, 2010.

NARODOWSKI, Mariano. Comenius \& a educação. Belo Horizonte: Autêntica, 2001.

SEBASTIÁN, Santiago. Contrarreforma y barroco: lecturas iconográficas e iconológicas. Madrid: Alianza Editorial, 1981.

XAVIER, Ismail. Um cinema que "educa" é um cinema que (nos) faz pensar: entrevista com Ismail Xavier. Educação \& Realidade (Dossiê cinema e educação), Porto Alegre, v. 33, n. 1, p.13-20, jan./jun. 2008.

WEISBACH, Werner. El barroco: arte de la contrarreforma. Madrid: Espasa; Calpe, 1948.

Data de registro: $15 / 12 / 2011$

Data de aceite:03/10/2012 